\title{
CONSERVATION AND MANAGEMENT IN THE FRENCH SUB-ANTARCTIC ISLANDS AND SURROUNDING SEAS
}

\author{
by M. Lebouvier and Y. Frenot \\ (with two text-figures and one table)
}

Lebouvier, M \& Frenot, Y. 2007 (23:xi). Conservation and management in the French sub-Antarctic islands and surrounding seas. Papers and Proceedings of the Royal Society of Tasmania 141(1): 23-28. https://doi.org/10.26749/rstpp.141.1.23 ISSN 0080-4703

Ecobio, Université de Rennes 1, CNRS, Station Biologique, 35380 Paimpont, France $\left(\mathrm{ML}^{*}\right)$; Institut Polaire Français Paul Emile Victor, BP 75, 29280 Plouzané, France (YF). *Author for correspondence.

Of the French islands in the Southern Indian Ocean, Archipel Crozet and Îles Kerguelen are considered sub-Antarctic, and Île Amsterdam and Île Saint-Paul temperate. All have endemic species amongst their biota. The Terres Australes et Antarctiques Françaises (TAAF) is responsible for sovereignty of these islands, the French Polar Institute (IPEV) is the central agency for research, and the Committee for the Polar Environment (CEP) provides advice on environmental protection and management issues. In 2006 all of the islands gained the status of Nature Reserve, and a management plan is expected to be in place within three years, providing greater protection for the environment and biota.

Key Words: sub-Antarctic islands, Archipel Crozet, Îles Kerguelen, île Saint-Paul, île Amsterdam.

Among the French islands located in the Southern Indian Ocean, two groups are really sub-Antarctic - Archipel Crozet, north of the Polar Front, and Îles Kerguelen, close to the Polar Front - whereas Île Amsterdam and Île Saint-Paul lie north of the subtropical convergence.

\section{ARCHIPEL CROZET}

\section{Location and physical characteristics}

Archipel Crozet consists of five main oceanic islands, Île aux Cochons, Île des Pingouins, Îlots des Apôtres, Île de la Possession and Île de l'Est (table 1 and fig. 1). These mountainous islands, entirely volcanic in origin, are split into two groups, western and eastern, $100 \mathrm{~km}$ apart. This archipelago has been built by several magmatic events which started 10 million years ago. Rocks are volcanic and plutonic in the eastern group, and volcanic in the western group (Giret et al. 2003).

The climate is oceanic, cold and windy: mean annual air temperature is $5.3^{\circ} \mathrm{C}$ with monthly mean temperatures ranging between $3.2^{\circ} \mathrm{C}$ in winter and $8.1^{\circ} \mathrm{C}$ in summer; total annual precipitation is around $2400 \mathrm{~mm}$; strong west winds are frequent. No permanent ice exists today but past glaciations have occurred as evidenced by large glacial valleys on Île de l'Est and Île de la Possession

\section{History}

After their discovery in 1772 by Marion-Dufresnethese islands were visited by sealers and whalers in the nineteenth century. The Alfred Faure permanent scientific and meteorological station (130 $\mathrm{m}$ a.s.l), was built in 1963-64 on the eastern coast of Île de la Possession. A small transitory population, around 40 people in summer and 25 people in winter, is present on this station.

\section{Flora and fauna}

Herbaceous vegetation occurs at low altitude. Above 150 $\mathrm{m}$ a.s.l. feldmark vegetation dominates. Twenty-four native vascular plantspecies have been recorded at Île de la Possession. Most of the flora belongs to the Southern Indian Ocean biogeographical province and there is no plant species endemic to the archipelago. Fifty-eight alien plant species have been

TABLE 1

Physical variables for each island of Archipel Crozet

\begin{tabular}{lcccc}
\hline & Position & Area, $\mathrm{km}^{2}$ & Altitude, $\mathrm{m}$ & Age, myr \\
\hline $\begin{array}{l}\text { Western group } \\
\text { Île aux Cochons }\end{array}$ & $46^{\circ} 05^{\prime} \mathrm{S}-50^{\circ} 15^{\prime} \mathrm{E}$ & 68.3 & 843 & $0.4-0.2$ \\
Île des Pingouins & $46^{\circ} 25^{\prime} \mathrm{S}-50^{\circ} 24^{\prime} \mathrm{E}$ & 5.6 & 340 & 1.1 \\
Îlots des Apôtres & $45^{\circ} 58^{\prime} \mathrm{S}-50^{\circ} 26^{\prime} \mathrm{E}$ & 3.4 & 292 & $5.5-2.6$ \\
Eastern group & & & & \\
Île de la Possession & $46^{\circ} 25^{\prime} \mathrm{S}-51^{\circ} 45^{\prime} \mathrm{E}$ & 147.1 & 934 & 8.1 \\
Île de l'Est & $46^{\circ} 25^{\prime} \mathrm{S}-52^{\circ} 15^{\prime} \mathrm{E}$ & 129.8 & 1090 & 8.7 \\
\hline
\end{tabular}




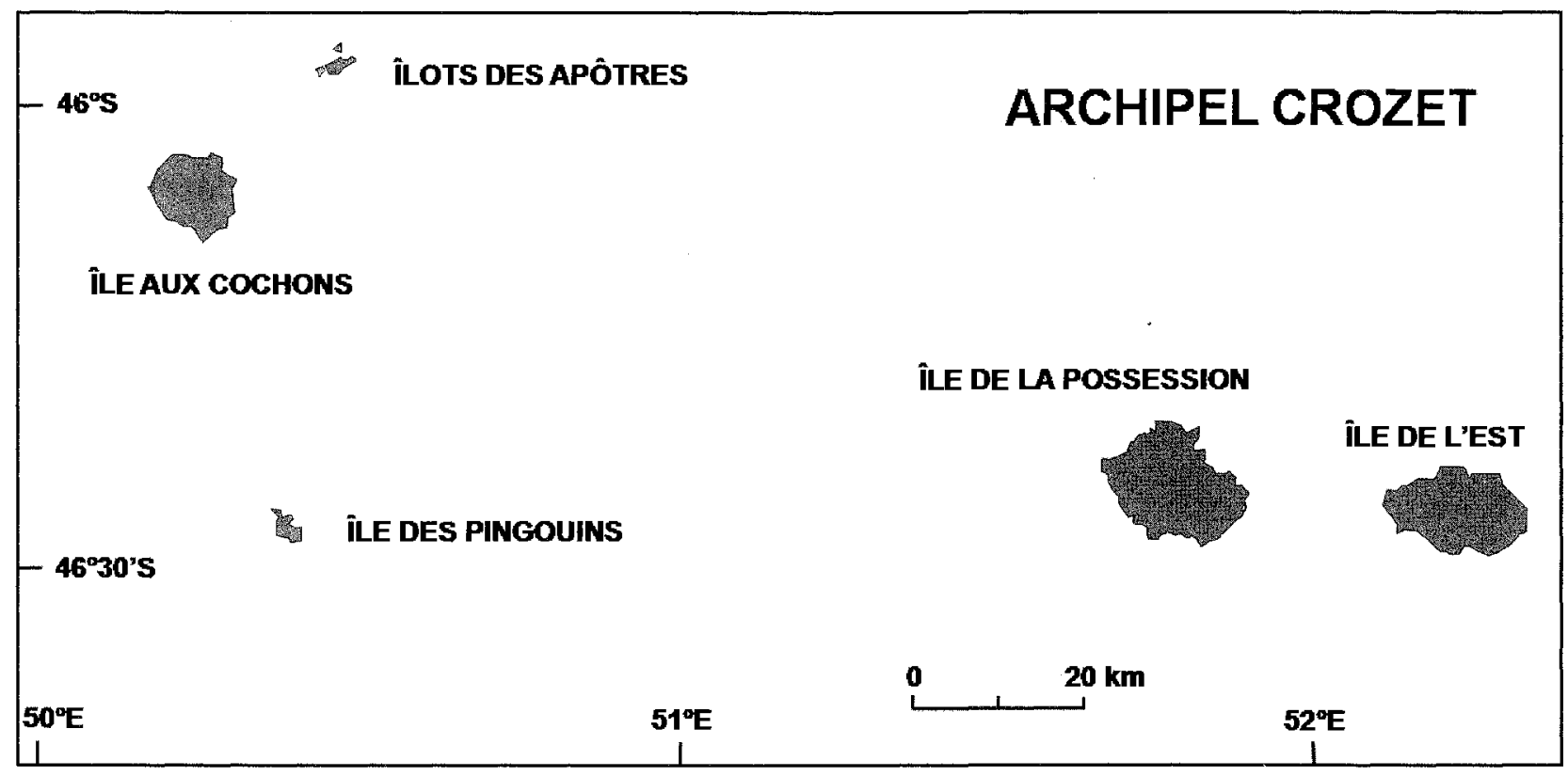

FIG.1 - General map of Archipel Crozet.

recorded at Île de la Possession. These species are localised around the Alfred Faure station with only seven species widely distributed over the island (Frenot et al. 2001).

The invertebrate fauna is characterised by a high level of endemism, especially for Diptera and Coleoptera. Alien invertebrates are few (14 species) and most are only present in the vicinity of the research station (Frenot et al. 2005).

Thirty-six species of seabirds breed in the archipelago. Île aux Cochons supports the largest King Penguin colony in the world with about 300000 pairs (Jouventin et al. 1984).

Five alien mammal species are present in the archipelago: the black rat Rattus rattus Linnaeus, 1758 on Île de la Possession, the rabbit Oryctolagus cuniculus (Linnaeus, 1758) on Île de l'Est and Île aux Cochons, the house mouse Mus musculus Linnaeus, 1758 and the cat Felis catus Linnaeus, 1758 on Île aux Cochons (Chapuis et al. 1994). Cats and rats greatly reduce the numbers of breeding seabirds.

\section{ÎLES KERGUELEN}

\section{Location and physical characteristics}

Îles Kerguelen lie between $48^{\circ} 30^{\prime}$ and $50^{\circ} \mathrm{S}$, and $68^{\circ} 27^{\prime}$ and $70^{\circ} 35^{\prime} \mathrm{E}$. This wide archipelago $\left(7200 \mathrm{~km}^{2}\right)$ consists of a main island $\left(6500 \mathrm{~km}^{2}\right)$, surrounded by dozens of smaller islands and numerous islets. The coastline is deeply indented, with numerous fords and, in the eastern part of the archipelago, a wide and relatively sheltered bay, Golfe du Morbihan. High mountains, several glaciers and an icecap (Calotte glaciaire Cook) occur in the western part of the main island. The highest point (Mont Ross) is $1850 \mathrm{~m}$ a.s.l.

These volcanic islands have developed over a very long period (the oldest rocks are around $30 \mathrm{Ma}$ ). Many characteristic and unusual features in their geological history led Giret et al. (1997) to consider Îles Kerguelen as a "third type of oceanic island". Hot springs in some places attest to a present volcanic activity.
The climate is oceanic and cold with strong westerly winds all year round. At Port-aux-Français station, in the eastern part of the main island, the mean annual air temperature is $4.6^{\circ} \mathrm{C}$ with monthly mean temperatures ranging between $2.0^{\circ} \mathrm{C}$ in July and $7.7^{\circ} \mathrm{C}$ in February; total annual precipitation is around $760 \mathrm{~mm}$ (Météo-France 1951-2005 records). However, rainfall is higher, up to 3500 $\mathrm{mm} / \mathrm{yr}$, in the western part of the archipelago. Climate has changed markedly over the past few decades (Frenot et al. 1997). The mean annual air temperature has increased by $1.3^{\circ} \mathrm{C}$ since the mid-1960s and the mean annual rainfall has decreased by $150 \mathrm{~mm}$ over the past 10 years at Portaux-Français (Chapuis et al. 2004).

\section{History}

After their discovery in 1772 by Kerguelen these islands were regularly visited by sealers and whalers in the late eighteenth and early nineteenth centuries, and subsequently, by several scientific expeditions, notably by expeditions to observe the transit of Venus in 1874. A whaling station was established in 1908 and worked intermittently until 1930. In 1913 an attempt to farm sheep, imported from the Falkland Islands, was unsuccessful (Arnaud \& Beurois 1996). The scientific and meteorological station, Port-aux-Français, was established in 1951 and has been permanently occupied since that date by a small transitory population of around 100 people in summer and 50 people in winter.

\section{Flora and fauna}

Twenty-nine native vascular plant species (22 phanerogam and seven pteridophyte) have been recorded at Îles Kerguelen. Most of the flora belongs to the Southern Indian Ocean biogeographic province and the only endemic species is Lyallia kerguelensis Hook. f. which is closely related to Hectorella caespitosa Hook. f. (Portulacaceae) of New Zealand (Wagstaff 
\& Hennion 2007). Amongst the 68 alien plant species recorded at Îles Kerguelen, 49 are present around the station at Port-aux-Français while seven invasive species are widely distributed within the archipelago (Frenot et al. 2001).

The total number of introduced and naturalised invertebrate species is high (30), compared with the numbers in other sub-Antarctic islands (Frenot et al. 2005). Amongst 39 insect species currently found at Îles Kerguelen 23 are endemic or sub-Antarctic and 16 are alien (SchermannLegionnet et al. 2007).

The avifauna is rich and diverse, with 35 breeding bird species (Weimerskirch et al. 1989).

Amongst the marine mammals, Southern Elephant Seals Mirounga leonina (Linnaeus, 1758) and Antarctic Fur Seals Arctocephalus gazella (Peters, 1875) breed at Îles Kerguelen. Their numbers have rebounded since the cessation in sealing.

Five salmonid fish and seven alien mammal species are present, having been introduced intentionally or unintentionally; they include black rats, rabbits, mice, cats, reindeer Rangifer tarandus Linnaeus, 1758, sheep Ovis aries Linnaeus, 1758 and Corsican mouflon Ovis musimon Pallas, 1762 (Chapuis et al. 1994).

The impact of the introduced mammals on the structure and functioning of the ecosystem is dramatic. Rabbits, present on many islands and widely distributed on Grande Terre, have greatly reduced the plant species diversity. For instance, the sub-Antarctic Acaena magellanica (Lam.) Vahl (Rosaceae) now occupies wide areas as nearly monospecific heathlands. In order to rehabilitate islands degraded by rabbits and to study the recovery of native plant communities a program of eradication by poisoning was implemented on three small islands from 1992 onwards (Chapuis et al. 2001). By the early 2000s rats had been eradicated on three small islands by conservation programs. Cats were introduced in 1956 to control rats and mice at Port-auxFrançais station. Their number and range have increased very quickly and a control program of shooting in the mid-1970s failed. Cats are responsible for the destruction of thousands of burrowing birds, mainly small petrels every year (Weimerskirch et al. 1989). Sheep and mouflon are currently present on two islands in Golfe du Morbihan, Île Longue and Île Haute respectively. After the introduction of 10 animals in 1956, reindeer have colonised a wide part of Grande Terre but the present size and distribution of the population are poorly known.

\section{ÎLE AMSTERDAM AND ÎLE SAINT-PAUL}

\section{Location and physical characteristics}

Île Amsterdam $\left(37^{\circ} 50^{\prime} \mathrm{S}, 77^{\circ} 30^{\prime} \mathrm{E}\right)$ and Île Saint-Paul (38 $43^{\prime} \mathrm{S}$, $\left.77^{\circ} 31^{\prime} \mathrm{E}\right)$ are very isolated islands located halfway between South Africa and Australia, close to the East Indian midoceanic ridge. Palaeomagnetic data suggest that the main part of Île Amsterdam arose during the period 400-200 kyr BP. However, numerous recent volcanic cones can be seen and the youngest was probably formed during the nineteenth century (Giret 1987). Île Amsterdam is elliptical in shape, about $9.2 \mathrm{~km}$ long by $7.4 \mathrm{~km}$ wide and $55 \mathrm{~km}^{2}$ in land area. The entire coastline, except for two locations in the northwest, is surrounded by steep cliffs, commonly 30-60 m high, rising up to $700 \mathrm{~m}$ in the western part, where the highest cliffs have been caused by a geological subsidence of a part of the volcano. The northern, eastern and southern slopes are concentric around an old caldera, le Plateau central, at 720 $\mathrm{m}$ a.s.l., which is dominated by the highest point, Mont de la Dives, peaking at $881 \mathrm{~m}$ a.s.l. Plateau des Tourbières is a large flat area between this high point and the western cliffs.

Île Saint-Paul, $80 \mathrm{~km}$ south of Île Amsterdam, is more recent than Île Amsterdam. Hot springs and fumarolic gas are still observed. Île Saint-Paul is a small crescent-shaped collapsed crater. A central lake crater with a diameter of $1000 \mathrm{~m}$ is open to the ocean and accessible to small boats by a narrow channel, $0.8-2.5 \mathrm{~m}$ in depth depending on the tide. The land area is $7 \mathrm{~km}^{2}$ and the highest point is $265 \mathrm{~m}$ a.s.l.

Due to its location north of the subtropical convergence the climate of Île Amsterdam is oceanic and mild. Strong westerly winds are frequent, especially in winter. The mean air temperature is $14.0^{\circ} \mathrm{C}\left(11.2^{\circ} \mathrm{C}\right.$ in August, $17.4^{\circ} \mathrm{C}$ in February). Cloudiness is high all year round and the mean annual rainfall at the meteorological station ( $27 \mathrm{~m}$ a.s.l.) is around $1100 \mathrm{~mm}$ distributed over 226 days; a dry period occurs in summer.

\section{History}

Île Amsterdam was discovered in 1522 by Sebastian del Cano, on one of Magellan's ships, on the way back to Europe after the first circumnavigation of the globe. However, the first known landing is attributed to the Dutch sailor Willem de Vlaming in 1696. The two islands were visited by sealers and fishermen from the late eighteenth century onwards. Seal harvesting was intense and fur seals Arctocephalus tropicalis (Gray, 1872) were considered extinct in the late nineteenth century. After cessation of harvesting the population recovered and has stabilised (Guinet et al. 1994). The second half of the nineteenth century was marked by several scientific visits (Novara in 1857, Transit of Venus in 1874-75) and by an attempt at settlement on Île Amsterdam by Heurtin, a farmer from Ille de la Réunion, in 1871. This attempt failed and Heurtin released five cattle Bos taurus Linnaeus, 1758 when leaving the island, one year later. The number of cattle quickly increased and was estimated at 1500 head in 1931 (Aubert de la Rüe 1932) and 2000 head in 1988 (Berteaux \& Micol 1992). Cattle have been a significant cause of ecosystem disturbance, especially at low altitude, in conjunction with successive fires mainly caused by human activities.

A scientific and meteorological station, Martin-de-Viviès, was established in 1949-50 on the northeastern coast of Île Amsterdam at $30 \mathrm{~m}$ a.s.l. This station hosts about 40 people in summer and 25 people in winter.

\section{Flora and fauna}

The native flora includes Sphagnum species (note that Sphagnum peatlands do not occur on either Îles Kerguelen, or Archipel Crozet) and, on Île Amsterdam, one species of tree, Phylica arborea Thouars. In the late 1980s the Phylica arborea forest reported by early visitors had been reduced to small patches. Much of the native vegetation had disappeared and introduced plant species had become dominant (Frenot \& Valleix 1990, Frenot et al. 2001).

The native invertebrate fauna includes endemic brachypterous or micropterous species, e.g., Brachypteragrostis patricei Viette, 1959 (Lepidoptera), Trimicra pauliani 
Séguy, 1959 (Diptera), mainly present above $400 \mathrm{~m}$ a.s.l. Some introduced species, Calliphora croceipalpis Jaennicke, 1867 (Diptera), Porcellio scaber Latreille, 1804 (Isopoda), Dendrodrilus rubidus tenuis Eisen, 1874 (Oligochaeta) are widely distributed at all altitudes (Tréhen et al. 1990).

Habitat destruction and introduced mammals (brown rats Rattus norvegicus Berkenhout, 1769 and cats) have threatened the avifauna at Île Amsterdam. One-third of the original avifauna was endemic. Several species have now become extinct and only 10 species of birds actually breed on this island (Micol \& Jouventin 1995), including the endangered Amsterdam Albatross Diomedea amsterdamensis Roux, Jouventin, Mougin, Stahl \& Wiemerskirch, 1993 discovered in 1983 (Jouventin \& Roux 1983). A restoration program was implemented in 1988 (Micol \& Jouventin 1995): cattle were removed from the larger part of the island, a fence was erected to protect the peat bogs at altitude and the breeding area of the Amsterdam Albatross, and about 10000 Phylica seedlings were planted between 1988 and 1993. At Île Saint-Paul, a small rock, La Quille, $100 \mathrm{~m}$ apart from the main island, is a sanctuary for several endemic bird species. Black rats and rabbits were eradicated from Île Saint-Paul in 1997 to allow these birds to re-colonise the main island. Mice are still present.

\section{COMMERCIAL ACTIVITIES AT FRENCH SUB-ANTARCTIC ISLANDS AND SURROUNDING SEAS}

Marine areas around Archipel Crozet and Îles Kerguelen are within the boundaries of the Convention on the Conservation of Antarctic Marine Living Resources (CCAMLR, 1982). Since 1994, exploitation of whales has been prohibited in the 200-mile Exclusive Economic Zone (EEZ) around the French sub-Antarctic islands, and commercial fishing here is strictly regulated. Measures include a ban on fishing in inshore waters, closed seasons and areas where appropriate, minimum size of fish, the need to hold a fishing licence, return of detailed catch records, and presence of observers at times.

Stock assessment and management are conducted with the expertise of Museum National d'Histoire Naturelle in Paris. The fight against illegal fishing is very active, including monitoring by satellite. The main targets of fisheries are the Patagonian toothfish Dissostichus eleginoides Smitt, 1898 and spiny lobsters Jasus paulensis Heller, 1862. Total allowable catches for the 2006-2007 season for Toothfish are 1100 tonnes at Archipel Crozet and 5000 tonnes at Îles Kerguelen in the EEZ, and for the lobster 390 tonnes at Île Amsterdam and Île Saint-Paul in territorial waters and in the EEZ.

Tourism in the French sub-Antarctic islands is strictly limited. Four times a year, eight to 16 tourists accompanied by a guide visit the islands briefly aboard the supply vessel Marion-Dufresne.

\section{CONSERVATION AND MANAGEMENT}

Several organisations are involved in activities in the French sub-Antarctic islands and interact for conservation and management issues. The Terres Australes et Antarctiques Françaises (TAAF), attached to the Ministry of Overseas Territories, is responsible for national sovereignty in the French sub-Antarctic islands. This overseas territory, created in 1955, is administered in Ile de La Réunion by a Préfet who is the representative of the French government. The Préfet is represented by a district head, replaced every year, at Alfred Faure, Port-aux-Français and Martin-de-Viviès stations.

The French Polar Institute (IPEV, Institut Polaire Français Paul Emile Victor), created in 1992, is the central agency for polar and sub-polar research. Several organisations are involved in this agency, namely: Ministry of Research, Ministry of Foreign Affairs, National Centre for Scientific Research (CNRS), French Research Institute for Exploitation of the Sea (IFREMER), French Atomic Energy Commission (CEA), Meteorological Agency (Météo-France), Space Agency (CNES), French Polar Expeditions (EPF) and TAAF.

The Committee for the Polar Environment (CEP), created in 1993, gives advice and recommendations on matters relating to environment and wildlife protection, protected areas, and management issues. The 11 members of this committee are appointed by several ministers: foreign affairs, environment, overseas territories, research and by the nature conservation council (Conseil National de la protection de la nature). Issues relevant to the environment can be referred to the CEP by these ministries, by the Préfet, or by the director of the French Polar Institute. Conservation and management in the French sub-Antarctic islands are regulated by successive laws and decrees. The 1938 National Park Act protected marine mammals (in particular fur seals and elephant seals) and some bird species. Specific access regulations became effective in 1985: access to some areas was reserved for scientific activities, and visits to several pristine or little-disturbed islands and areas were strictly restricted and had to be justified by compelling scientific aims. Since 2001, a TAAF committee has been in charge of surveys, inventories and conservation of historical and cultural sites.

Most of the previous regulations were reinforced in October 2006 when the islands were given the status of Nature Reserve (Réserve Naturelle nationale des Terres australes Françaises, decree n²006-1211, 03/10/2006) which is the strongest protection available under French law. The Nature Reserve includes all terrestrial areas, internal and territorial waters of the three groups of islands, except for the territorial waters around Île de La Possession (Archipel Crozet) and several marine areas at Îles Kerguelen (fig. 2). The Préfet is in charge of the reserve management. The TAAF consultative committee is designated as the consultative committee for the Nature Reserve and the CEP is designated as the scientific committee to be consulted about the management plan and about every scientific issue relevant to environment. This management plan is being drawn up within a three-year period following the creation of the Natural Reserve on 3 October 2006. At present it is only possible to introduce the general regulations mentioned in the establishment decree. Regulations for terrestrial areas state:

- The importation of non-domestic animals to the reserve is prohibited.

- The importation of domestic animals is prohibited except for animals involved in public service or rescue tasks (this exception is likely related to shepherd dogs which are sometimes present at Îles Kerguelen where sheep farming occurs).

- It is forbidden to disturb, to damage, to export wild animals as well as their eggs, litter or nests, except for scientific or health purposes subject to authorisation.

- The importation of plants in any form is prohibited, 


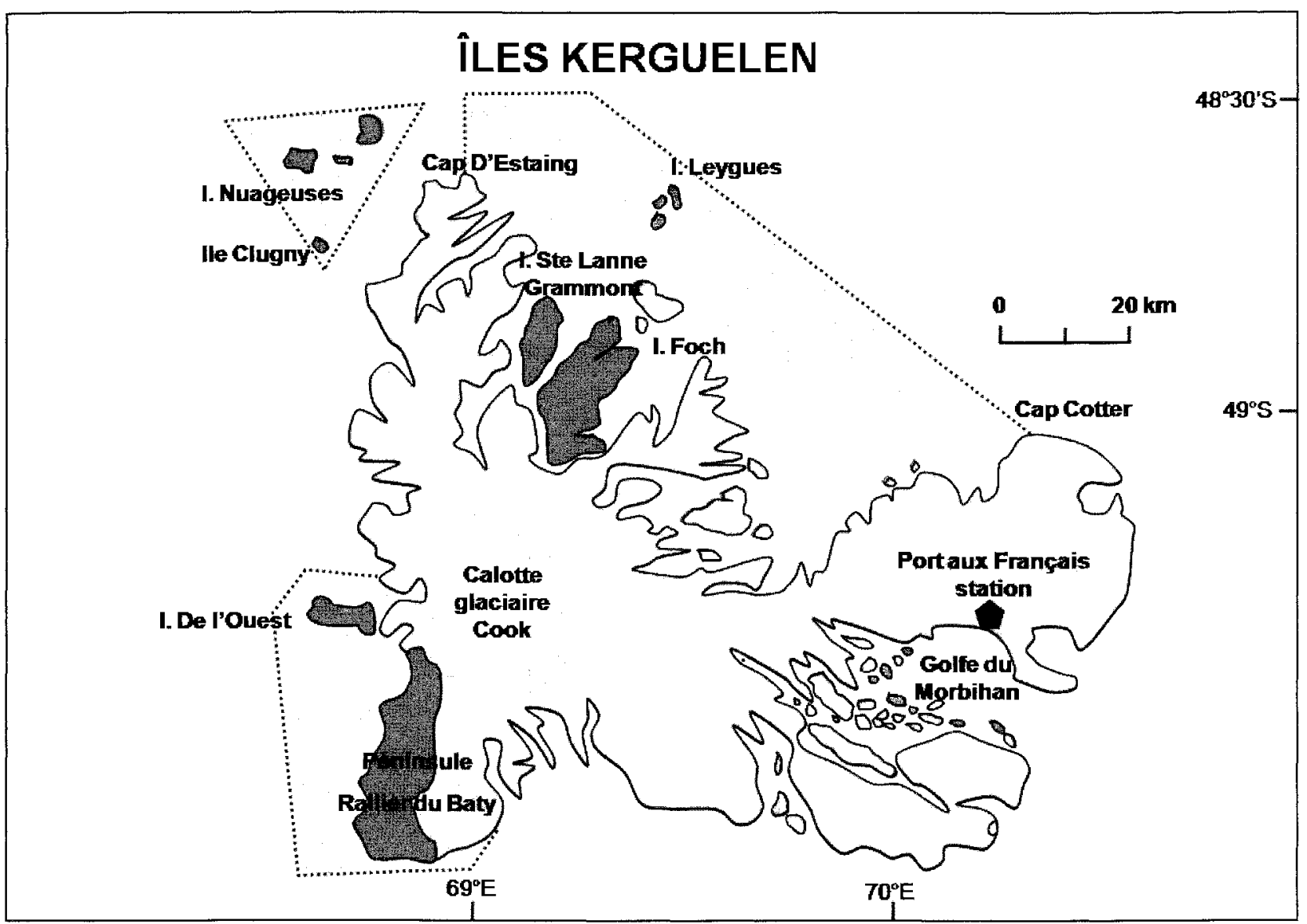

FIG. 2 - General map of Iles Kerguelen with the specially protected areas (dark grey) and the marine areas (hatched) included in the Nature Reserve.

except for the provision of the stations. (Greenhouse cultivation occurs at Crozet and Kerguelen islands, as well as outdoor gardening at Amsterdam Island).

- It is forbidden to damage wild plants, except for care tasks in the reserve, and to export them, except for authorised scientific, medical or paramedical purposes.

- Mineral prospecting and mining are prohibited.

- No geological samples may be collected or transported except for authorised scientific purposes.

- Various activities are regulated by the Préfet in accordance with the management plan of the Nature Reserve: control of alien species, waste management, fishing in fresh water, farming, tourism, sport, photography, filming.

Regulations for marine areas state:

- Fishing in the Nature Reserve is controlled by the Préfet.

- It is prohibited to destroy, to mutilate, to capture and to remove cetaceans.

- The location and use of anchorages are specified by the Préfet in accordance with the management plan.

- Apart from the authorised anchorages, vessels are allowed only to cross the marine areas included in the Nature Reserve.

\section{Specially protected areas}

The highest level of protection applies to some areas where any human activity is prohibited. Access to these areas is unauthorised except in the case of force majeure. However, dispensations may be granted.
The specially protected areas are the following: Îles Kerguelen (fig. 2): the west coast of Péninsule Rallier du Baty, Îles Nuageuses, Îles Leygues, île Cluny, Île de l'Ouest, Île Saint-Lanne-Grammont, Ile Foch and several small islands in Golfe du Morbihan (Hoskyn, Pender, Bryer, Blackeney, Greak, Suhm, Antarès); Archipel Crozet: Île de l'Est, Île des Pingouins, Îlots des Apôtres, Île aux Cochons ; and Île Saint-Paul: the entire island.

It is anticipated that the new status of Nature Reserve will increase the overall protection of the terrestrial and marine environments and of the biotas of the French subAntarctic islands.

\section{ACKNOWLEDGEMENTS}

The authors are grateful for the research resources of the French Polar Institute (Programme 136) and the CNRS (Zone Atelier de Recherches sur l'environnement antarctique et subantarctique). ML thanks the Comité National Français de Recherches Antarctiques for supporting his participation in the sub-Antarctic Forum. The authors are grateful to P. Selkirk, P. Quilty, H. Dartnall and M. Davies for helpful comments and improvement of the manuscript. 


\section{REFERENCES}

Arnaud, P.M. \& Beurois, J. 1996: The shipowners of the dream. The Bossiere's leases and the exploitations of the French companies in the Southern Indian Ocean (1893-1939). Mme Jambois, Marseille: 116pp.

Aubert de la Rüe, E. 1932: La flore et la faune des Iles Saint-Paul et Amsterdam. Revue d'Ecologie (Terre et Vie) 2: 642-662.

Berteaux, D. \& Micol T. 1992: Population studies and reproduction of the feral cattle (Bos taurus) of Amsterdam Island, Indian Ocean. Journal of Zoology 228: 265-276.

Chapuis, J.-L., Boussès, P. \& Barnaud, G. 1994: Alien mammals, impact and management in the French sub-Antarctic islands. Biological Conservation 67: 97-104.

Chapuis, J.-L., Le Roux, V., Asseline, J., Lefevre, L. \& Kerleau, F. 2001: Eradication of the rabbit (Oryctolagus cuniculus) by poisoning, on three islands of the sub-Antarctic Archipelago of Kerguelen. Wildlife Research 28: 323-331.

Chapuis, J.-L., Le Roux, V., Asseline, J., Lefevre, L. \& Kerleau, F. 2001: Eradication of the rabbit (Oryctolagus cuniculus) by poisoning, on three islands of the sub-Antarctic Archipelago of Kerguclen. Wildlife Research 28: 323-331.

Chapuis, J.-L., Frenot, Y. \& Lebouvier, M. 2004: Recovery of native plant communities after eradication of rabbits from the sub-Antarctic Kerguelen Islands, and influence of climate change. Biological Conservation 117: 167-179.

Frenot, Y., Chown, S.L., Whinam, J., Selkirk, P., Convey, P., Skotnicki, M. \& Bergstrom, D. 2005: Biological invasions in the Antarctic: extent, impacts and implications. Biological Reviews 80: 45-72.

Frenot, Y., Gloaguen, J.C., Massé, L. \& Lebouvier, M. 2001: Human activities, ecosystem disturbance and plant invasions in sub-Antarctic Crozet, Kerguelen and Amsterdam Islands. Biological Conservation 101: 33-50.

Frenot, Y., Gloaguen, J.C. \& Tréhen, P. 1997: Climate change in Kerguelen islands and colonization of recently-deglaciated areas by Poa kerguelensis and Poa annua. In Battaglia, B., Valencia, J., Walton, D.W.H. (eds): Antarctic Communities: Species, Structure and Survival. Cambridge University Press, Cambridge: 358-366.

Frenot, Y. \& Valleix, T. 1990: Carte des sols de l'Ile Ansterdam (Terres Australes et Antarctiques Françaises). Comité National Français de Recherches Antarctiques 59: 1-48.

Giret, A. 1987: Géologie des Terres Ausurales Françaises. Comité National Franfais de Recherches Antarctiques 58: 17-41.
Giret, A., Grégoire, M., Cottin, J.Y. \& Michon, G. 1997: Kerguelen, a third type of oceanic island? In Ricci, C.A. (ed.): The Antarctic Region: Geological Evolution and Processes. Terra Antarctica Publication, Siena: 735-741.

Giret, A., Weis, D., Zhou, X., Cottin, J.-Y. \& Tourpin, S. 2003: Géologie des îles Crozet. Géologue 137: 15-23.

Guinet, C., Jouventin, P. \& Georges, J.Y. 1994: Long term population changes of fur seals Arctocephalus gazella and Arctocephalus tropicalis on sub-Antarctic (Crozet) and subtropical (St. Paul and Amsterdam) islands and their possible relationship to El Ninó Southern Oscillation. Antarctic Science 6: 473-478.

Jouventin, P. \& Roux, J.P. 1983: The discovery of a new albatross. Nature 305: 181.

Jouventin, P., Stahl, J.C., Weimerskirch, H. \& Mougin, J.L. 1984: The seabirds of the french sub-Antarctic islands and Adelie land, their status and conservation. In Croxall, J.P., Evans, P.G.H. \& Schreiber, R.W. (eds): Status and Conservation of the World's Seabirds. International Council for Bird Preservation, Technical Publication 2, Cambridge: 609-625.

Micol, T. \& Jouventin, P. 1995: Restoration of Amsterdam Island, South Indian Ocean, following control of feral cattle. Biological Conservation 73: 199-206.

Schermann-Legionnet, A., Hennion, F., Vernon, P. \& Atlan, A. 2007: Breeding system of the sub-Antarctic plant species Pringlea antiscorbutica R. Br. and search for potential insect pollinisators in the Kerguelen Islands. Polar Biology 30:1 183-1193.

Tréhen, P., Frenot, Y., Lebouvier, M. \& Vernon, P. 1990: Invertebrate fauna and their role in the degradation of cattle dung at Amsterdam Island. In Kerry, K.R. \& Hempel, G. (eds): Antarctic ecosystems. Ecological Change and Conservation. Springer, Berlin Heidelberg: 337-346.

Wagstaff, S.J. \& Hennion, F. 2007: Evolution and biogeography of Lyallia and Hectorella (Portulacaceae), geographically isolated sisters from the Southern hemisphere. Antarctic Science. doi: 10.1017/50954102007000648

Weimerskirch, H., Zotier, R. \& Jouventin, P. 1989: The avifauna of the Kerguelen Islands. Emu 89: 15-29.

(accepted 30 July 2007) 